\title{
Effects of milking interval and cisternal udder evaluation in Tunisian Maghrebi dairy dromedaries (Camelus dromedarius L.)
}

\author{
M. Ayadi, ${ }^{*}$ M. Hammadi, $\uparrow$ T. Khorchani, $\uparrow$ A. Barmat, $\nmid$ M. Atigui, $\nmid$ and G. Caja ${ }^{1}$ \\ *Institut Supérieur de Biologie Appliquée de Médenine, 4119 Médenine, Tunisia \\ †Laboratoire d'Elevage et Faune Sauvage, Institut des Régions Arides, km 22.5 Route Djorf, 4119 Médenine, Tunisia \\ $\ddagger$ Grup de Recerca en Remugants (G2R), Departament de Ciència Animal i dels Aliments, Universitat Autònoma de Barcelona, \\ 08193 Bellaterra, Spain
}

\section{ABSTRACT}

Effects of 4 different milking intervals (8, 12, 16, and $24 \mathrm{~h}$ ) on milk yield and milk composition were studied in Tunisian Maghrebi dairy dromedaries (n $=6$ ) at late lactation [240 \pm 14 days in milk (DIM), $5.84 \pm 1.62 \mathrm{~L} / \mathrm{d}]$. Camel-cows suckled their calves for 2 mo, were hand milked while suckling until mo 4 of lactation (calf weaning) and machine milked thereafter. Intravenous injection of oxytocin was administered before machine milking at each experimental milking to induce complete milk ejection and to avoid carryover effects of milking intervals. Cisternal and alveolar milk were measured at $380 \pm 16$ DIM for a 24 -h milking interval. Milk accumulated logarithmically $\left(\mathrm{R}^{2}=0.95\right)$ in the udder from 8- to 24-h milking interval without reaching a plateau. Consequently, milk secretion rate decreased exponentially $\left(\mathrm{R}^{2}=0.93\right)$ according to milking interval. Compared with 12 -h milking interval (6.1 L/d), estimated daily milk yield was 113,87 , and $70 \%$ for 8-, 16-, and 24-h intervals, respectively. Total milk solids, milk fat content, and milk $\mathrm{pH}$ decreased with increasing milking interval, showing the greatest value at 8-h intervals $(14.1 \pm 0.4 \%, 4.6 \pm 0.5 \%$, and $6.66 \pm$ 0.05 , respectively) and the lowest at 24 -h intervals ( 12.3 $\pm 0.9 \%, 2.9 \pm 0.6 \%$, and $6.54 \pm 0.02$, respectively). Milk protein $(3.9 \pm 0.1 \%)$, lactose $(4.5 \pm 0.2 \%)$, ash $(0.84 \pm 0.01 \%)$ and density $(1.028 \pm 0.01)$ remained constant for all milking intervals. Milk K, Ca, and $\mathrm{Mg}$ contents increased as milking interval increased, but $\mathrm{Na}$ content did not change $(0.06 \pm 0.01 \%$, on average $)$. Milk Na:K ratio tended to decrease from 0.35 (1:2.9) to 0.22 (1:4.5) for the extreme milking intervals. Plasma lactose concentration steadied from 8- to 16 -h $(67 \pm 32$ $\mu \mathrm{mol})$ but increased dramatically at 24-h intervals (338 $\pm 118 \mu \mathrm{mol})$, indicating that mammary tight junctions became permeable after $24 \mathrm{~h}$ of milk accumulation.

Received June 11, 2008.

Accepted November 4, 2008.

${ }^{1}$ Corresponding author: gerardo.caja@uab.cat
Camel udders showed small cisterns (19.3\% of total milk in the udder at $24 \mathrm{~h}$ ) when compared with other dairy animals; we recommend the use of prestimulation for machine milking and selection for larger udder cisterns. Alveolar milk contained more fat (5.16 vs. 1.75\%; SEM, $0.39 \%$ ) and protein (3.23 vs. $2.73 \%$; SEM, $0.15 \%$ ) than cisternal milk. Despite the increase of plasma lactose during tight junction leakiness, the tendency for the $\mathrm{Na}: \mathrm{K}$ ratio to decrease may be indicative of a camel's specific regulatory mechanism for controlling $\mathrm{Na}$ and $\mathrm{K}$ concentrations in milk and delaying the inhibitory effect of milk stasis on milk secretion rate. In conclusion, this short-term study proved the low storage capacity of the Tunisian Maghrebi camel udder but also showed their moderate ability to adapt to extended milking intervals at late lactation.

Key words: lactation, milk secretion, tight junction, dromedary

\section{INTRODUCTION}

The Maghrebi dromedary (Camelus dromedarius L.), also called Maghrabi one-humped camel, population of Tunisia is estimated at approximately 100,000 animals (Hammadi et al., 2006). Milk is considered a secondary product and milk yield of the Maghrebi camel is 2.0 L/d on average (El-Hatmi et al., 2004). However, under more favorable climatic conditions, as in the north of the country or under the intensive oasis production system, milk yield usually ranges between 6 and $12 \mathrm{~L} / \mathrm{d}$ (Kamoun, 1995; Hammadi et al., 2006). On these farms, twice-a-day milking (12-12- or 8-16-h milking intervals) is the most common milking frequency schedule. Camel milk production is affected by their adaptation to the desert conditions, resulting in a late first breeding (3 to $4 \mathrm{yr}$ in females), restricted breeding season (November to April), induced ovulation, long pregnancy (13 mo) and calving interval (2 yr).

Effects of milking interval on milk yield and milk composition depend on animal species, breed, and individuals. Accumulation of milk in the udder during extended milking intervals reduces the activity of mam- 
mary cells as a result of a local intramammary regulation (Stelwagen et al., 1997; Hernández et al., 2008). Moreover, there is a general agreement that increasing milking frequency to more than twice daily increases milk yield, but effects of both shortened and extended milking intervals are less marked in large-cisterned animals (Knight and Dewhurst, 1994; Ayadi et al., 2003; Castillo et al., 2008).

Effect of milking interval on milk secretion rate in hand-milked camels was shown by Alshaikh and Salah (1994) in a study conducted in Arabian dromedaries for 4- to 16-h milking intervals in which the greatest milk secretion rate $(585 \mathrm{~g} / \mathrm{h})$ was observed for the shortest milking interval. Although no differences between 8- and 12-h milking intervals were reported $(76 \%$ on average), milk secretion decreased to $67 \%$ for the $16-\mathrm{h}$ milking interval. No information is available on the size of the udder cisterns and the effects of machine milking and longer milking intervals (e.g., once-daily milking) in camels, the last being of especially practical interest at the end of lactation.

Previous studies done on hand-milked dairy camels reported an increase in milk yield according to milking frequency (i.e., 3 times daily, 5 to 10\%; 4 times daily, 30\%; Alshaikh and Salah, 1994; Kamoun, 1995). On the contrary, reducing milking frequency to $16 \mathrm{~h}$ (1.5 milkings per day) in camels decreased milk yield by $9 \%$ in late lactation (Alshaikh and Salah, 1994). Milk constituents generally followed similar patterns of decreasing content with increasing milking intervals although there is little information available (Alshaikh and Salah, 1994).

The decrease in milk yield observed as a result of long milking intervals $(>16 \mathrm{~h}$ ) is associated with the disruption of mammary tight junctions (TJ), which results in a rise in plasma lactose and $\mathrm{Na}: \mathrm{K}$ ratio in milk and of serum albumin in milk, occurring at approximately $18 \mathrm{~h}$ in dairy cows (Stelwagen et al., 1994a,; Delamaire and Guinard-Flament, 2006), and $20 \mathrm{~h}$ in dairy goats (Stelwagen et al., 1994b) and dairy ewes (Castillo et al., 2008).

The aim of the present study was to investigate the short-term effects of different milking intervals on milk yield and milk composition in dairy camels, as well as to bring new information on mammary TJ permeability and size of udder cisterns in dairy camels at late lactation.

\section{MATERIALS AND METHODS}

The experimental procedures and animal care conditions followed the Tunisian and Spanish laws on wellbeing and good practices in livestock.

\section{Animals, Feeding, and Routine Milking}

Six multiparous $(9.3 \pm 1.5$ yr of age; $463 \pm 13 \mathrm{~kg}$ BW) Maghrebi dairy camel cows from the experimental farm of the Arid Regions Institute (IRA, Médenine, Tunisia) were used after winter calving. Camels were group penned in loose stalls $\left(20 \mathrm{~m}^{2} /\right.$ camel $)$ with straw-bedded shelter and exercise area throughout the experiment. Daily ration per animal consisted of a forage mixture consisting of $5 \mathrm{~kg}$ of alfalfa hay (DM, 89.6\%; CP, $14.8 \%$; $\mathrm{NDF}, 42.2 \%$; $\mathrm{NE}_{\mathrm{L}}, 1.22 \mathrm{Mcal} / \mathrm{kg}$; on DM basis), $5 \mathrm{~kg}$ of oat hay (DM, 91.8\%; CP, $6.2 \%$; NDF, $68.4 \%$; $\mathrm{NE}_{\mathrm{L}}, 0.85$ $\mathrm{Mcal} / \mathrm{kg}$; on DM basis), and $8 \mathrm{~kg}$ of fresh alfalfa (DM, $15.0 \%$; CP, $18.7 \%$; NDF, $40.1 \%$; $\mathrm{NE}_{\mathrm{L}}, 1.28 \mathrm{Mcal} / \mathrm{kg}$; on DM basis), supplemented with $2 \mathrm{~kg}$ of a commercial concentrate (DM, 92.8\%; CP, 20.6\%; $\mathrm{NE}_{\mathrm{L}}, 1.73 \mathrm{Mcal} /$ $\mathrm{kg}$; on DM basis). Ad libitum access to clean water was ensured by use of a water tank.

Calving interval was approximately 25 mo (pregnancy, $12 \mathrm{mo}$; lactation, $13 \mathrm{mo}$ ), according to the traditional Tunisian camel production system. Colostrum was entirely sucked by the camel-calves which suckled ad libitum from their dams during the first 2 mo of age.

Twice-daily milking (0800 and $1600 \mathrm{~h}$ ) was initiated at mo 3 of lactation, at which time calves were penned separately from their dams. Milk let-down was induced by allowing the calf to suck only the 2 right teats of the udder whereas the 2 left teats were manually milked by an experienced milker. Camel-calves were weaned at 4 mo of age, and lactating camel-cows were introduced for the first time to machine milking using a restraining stall and a portable milking machine (Agromilk, Agro-service, Tunis, Tunisia). The milking machine was set at $48 \mathrm{kPa}, 60$ pulses/min, and 60:40 pulsation ratio. The milking routine included teat washing and drying, machine milking, machine stripping, and teat dipping (Polycide, Laboratoires Interchem, Tunis, Tunisia). Twice-daily milking was maintained until mo 12 of lactation, at which time the camels went to graze on a halophyte pasture (estimated intake, $6 \mathrm{~kg}$ of $\mathrm{DM} / \mathrm{d}$ ) and milking frequency passed to only once daily (0800 h)

\section{Milking Interval Study}

Effects of milking interval were studied at late lactation $(240 \pm 14$ DIM, $5.84 \pm 1.62 \mathrm{~L} / \mathrm{d})$. All camels were fully adapted to machine milking and were healthy and free of mastitis at the start of the experimental periods. Experimental design consisted of a crossover with 6 animals and 4 milking intervals $(8,12,16$, and $24 \mathrm{~h}$ ) allocated at random and replicated in 2 wk with an intermediate washout period of $1 \mathrm{wk}$. 
Before each experimental milking, blood samples from the jugular vein were taken, using heparinized Vacutainer tubes (LH 85 IU, Becton, Dickinson and Company, Plymouth, UK). Blood samples were immediately refrigerated and centrifuged for 15 min at 900 $\times g$ at $4^{\circ} \mathrm{C}$. Plasma samples were collected and stored at $-20^{\circ} \mathrm{C}$ for lactose analysis.

Approximately $1 \mathrm{~min}$ before milking, $10 \mathrm{IU}$ of synthetic oxytocin (Biocytocine, Laboratoires Biové, Arques, France) was injected in the jugular vein of each camel before milking to allow a complete udder emptying (all alveolar and cisternal milk) at each milking interval. Milk yield was recorded by volume (with an accuracy of $10 \mathrm{~mL}$ ) and sampled in triplicate for physical (density and $\mathrm{pH}$ ) and chemical analyses (total solids, fat, protein, ash, and minerals).

\section{Cisternal and Alveolar Udder Compartments}

Milk partitioning between cisternal and alveolar udder compartments (recorded by volume, precision 50 $\mathrm{mL}$ ) was studied on 2 test days at late lactation $(380 \pm$ $16 \mathrm{DIM} ; 1.60 \pm 0.90 \mathrm{~L} / \mathrm{d}$ ) during the period of once-aday milking (24-h milking interval).

With this aim, camel-cows were randomly nominated and moved individually to a restraining pen (unfamiliar surroundings) to reach a stressful situation thus preventing spontaneous milk letdown during udder manipulation according to Bruckmaier et al. (1993). Behavior exhibited by the camels proved that stressful conditions were achieved and strong and careful restraint was required to avoid injuries both to the animals and operators. Cisternal milk was collected by hand milking. Alveolar milk was collected by sequential machine milking after an i.v. injection of oxytocin (10 IU/camel; Biocytocine). Milk samples of each udder fraction (600 $\mathrm{mL}$ ) were collected and processed immediately after milking or stored at $4^{\circ} \mathrm{C}$ until analysis without using preservatives.

\section{Sample Analyses}

A first sample of $500 \mathrm{~mL}$ was used immediately after milking to determine milk $\mathrm{pH}$ and density. Milk $\mathrm{pH}$ was measured with a $\mathrm{pH}$ meter (Thermo Orion, Model 420A+, Thermo Scientific, Breda, the Netherlands) and milk density was assessed by using a thermolactodensimeter (Funke-Gerber, Berlin, Germany). Two more samples $(50 \mathrm{~mL})$ were refrigerated to $4^{\circ} \mathrm{C}$ and transported to the laboratory for chemical and bacteriological analyses according to International Dairy Federation (IDF) standards.

Total milk solids (IDF, 1987; IDF 21B) and ash (IDF, 1964; IDF 027) were analyzed by gravimetry.
Milk CP $(\mathrm{N} \times 6.38)$ was determined by titration using the Kjeldahl method (IDF, 2001; IDF 020-1) and fat was determined by using butyrometers (IDF, 1981; IDF 105). Milk $\mathrm{Ca}, \mathrm{Mg}, \mathrm{K}$, and $\mathrm{Na}$ contents were determined from ash by atomic absorption spectrometry (Hitachi Z-6100, Hitachi Instruments Engineering, Ibaraki, Japan) in the presence of lanthanum oxide (1\%; Sigma, St. Louis, MO) to overcome phosphate interference with $\mathrm{Ca}$ and $\mathrm{Mg}$, and in the presence of the cesium chloride for $\mathrm{K}$ and Na. Hydrochloric acid $6 N$ was used to dissolve ashes.

Udder health for each udder quarter was assessed at each experimental milking using the California mastitis test (Hauptner, Solingen, Germany). Routine bacteriological milk analyses were also done for total aerobic mesophilic bacteria to detect intramammary infections. Lactose in plasma was analyzed by using a lactose and galactose enzymatic kit (Lactose/D-Galactose UVmethod, Boehringer Mannheim/R-Biopharm, Darmstadt, Germany).

\section{Statistical Analyses}

Data were processed by the PROC MIXED procedure for repeated measurements of SAS (SAS version 9.0, SAS Inst. Inc., Cary, NC). The model included the general mean and the fixed effects of milking intervals $(8$, 12,16 , and $24 \mathrm{~h}$ ) and the random effects of animals (1 to 6 ), their interactions and the residual error. Differences between least squares means were determined with the PDIFF test. Pearson correlation coefficients between measurements were also calculated. Significance was declared as $P<0.05$ unless otherwise indicated.

\section{RESULTS AND DISCUSSION}

\section{Milk Yield and Milk Secretion Rate}

The California mastitis test analysis revealed that 1 camel developed clinical mastitis in an udder quarter during wk 2 of the experiment. Intramammary infection was confirmed by milk bacteriology and data of this camel were excluded from the milking interval study. Nevertheless, after treatment with intramammary antibiotic (Mastijet, Intervet, Angers, France) and bacteriological testing, the camel was used again in the udder compartment study. Changes in the volume of milk yield and milk composition according to milking interval are summarized in Table 1. Milk volume accumulated in the camel mammary glands increased with time elapsed after the last milking for the 8- to 24-h milking intervals studied. Both linear and logarithmic models satisfactorily fit the observed values; the prediction equations being ( $\mathrm{y}$ is milk volume in liters and $\mathrm{x}$ is milking interval in hours; $P<0.001)$ : 


$$
\begin{gathered}
\mathrm{y}=1.46+0.123 \mathrm{x} ; \mathrm{R}^{2}=0.952 ; \\
\mathrm{y}=-1.46+1.811 \operatorname{Ln} \mathrm{x} ; \mathrm{R}^{2}=0.953 .
\end{gathered}
$$

The logarithmic equation more accurately expressed milk accumulation changes in the udder of the camels, although nonreal values were obtained when extrapolated for milking intervals of less than $4 \mathrm{~h}$. Milk secretion rate decreased in an exponential manner $\left(\mathrm{R}^{2}=\right.$ 0.929, $P<0.001$ ) as milking interval increased (Figure 1 ), the equation being ( $\mathrm{y}$ is milk secretion rate in milliliters per hour and $\mathrm{x}$ is milking interval in hours):

$$
\mathrm{y}=505-102.2 \operatorname{Ln} \mathrm{x} .
$$

Estimated milk secretion rate in the camel udders was greatest for the shortest milking interval $(8 \mathrm{~h})$ and extrapolation showed a value not different from zero after $72 \mathrm{~h}$ of milk stasis. Although we injected oxytocin in the jugular vein of each camel before milking to allow a complete udder emptying (all alveolar and cisternal milk), milk secretion rate values were smaller but in the range of those previously reported by Alshaikh and Salah (1994) for the same milking intervals.

As a result, predicted daily milk yield decreased when milking interval increased ( 8 to $24 \mathrm{~h}$ ) and daily milking frequency was reduced (3 to 1 milkings daily). Calculated equation for predicted daily milk yield between 8- and 24-h milking intervals was (y is daily milk yield

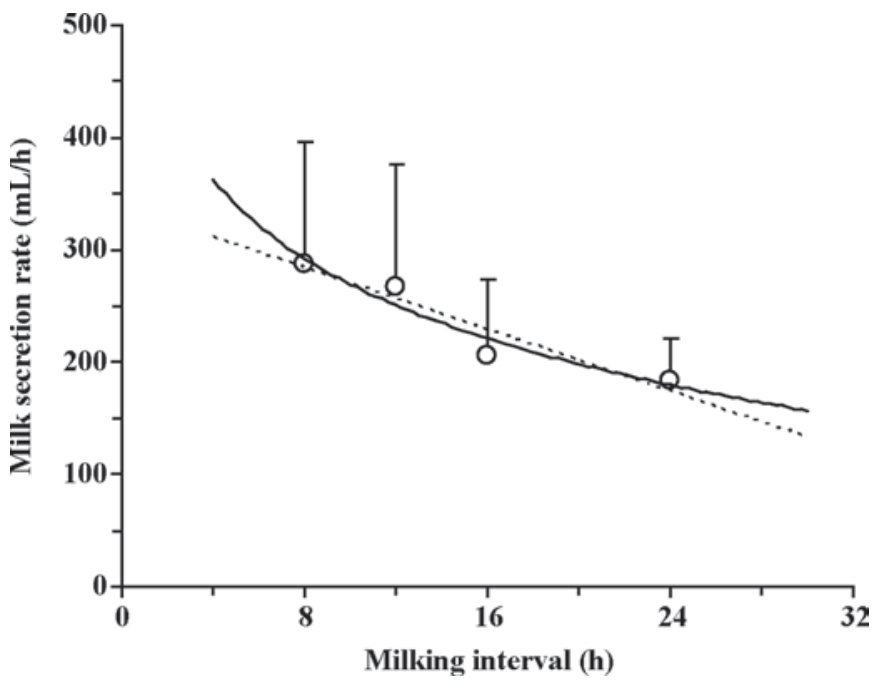

Figure 1. Milk secretion rates $(\mathrm{mL} / \mathrm{h})$ per milking interval $(\mathrm{h})$ in dairy camels (vertical bars represent SEM). Regression equations are: linear (dotted line; $\mathrm{R}^{2}=0.90, P<0.001$ ) $\mathrm{y}=338-6.83 \mathrm{x}$ and logarithmic (solid line; $\mathrm{R}^{2}=0.93, P<0.001$ ) $\mathrm{y}=505-102.2 \operatorname{Ln} \mathrm{x}$.

in liters per day and $\mathrm{x}$ is milking interval in hours; $\mathrm{R}^{2}$ $=0.997, P<0.001)$ :

$$
\mathrm{y}=11.96-2.398 \operatorname{Ln} \mathrm{x} .
$$

The pattern of milk yield change with increasing milking interval observed in our study agreed with previous observations reported in dairy camels by Alshaikh and

Table 1. Milk yield and milk composition of dairy camels at different milking intervals

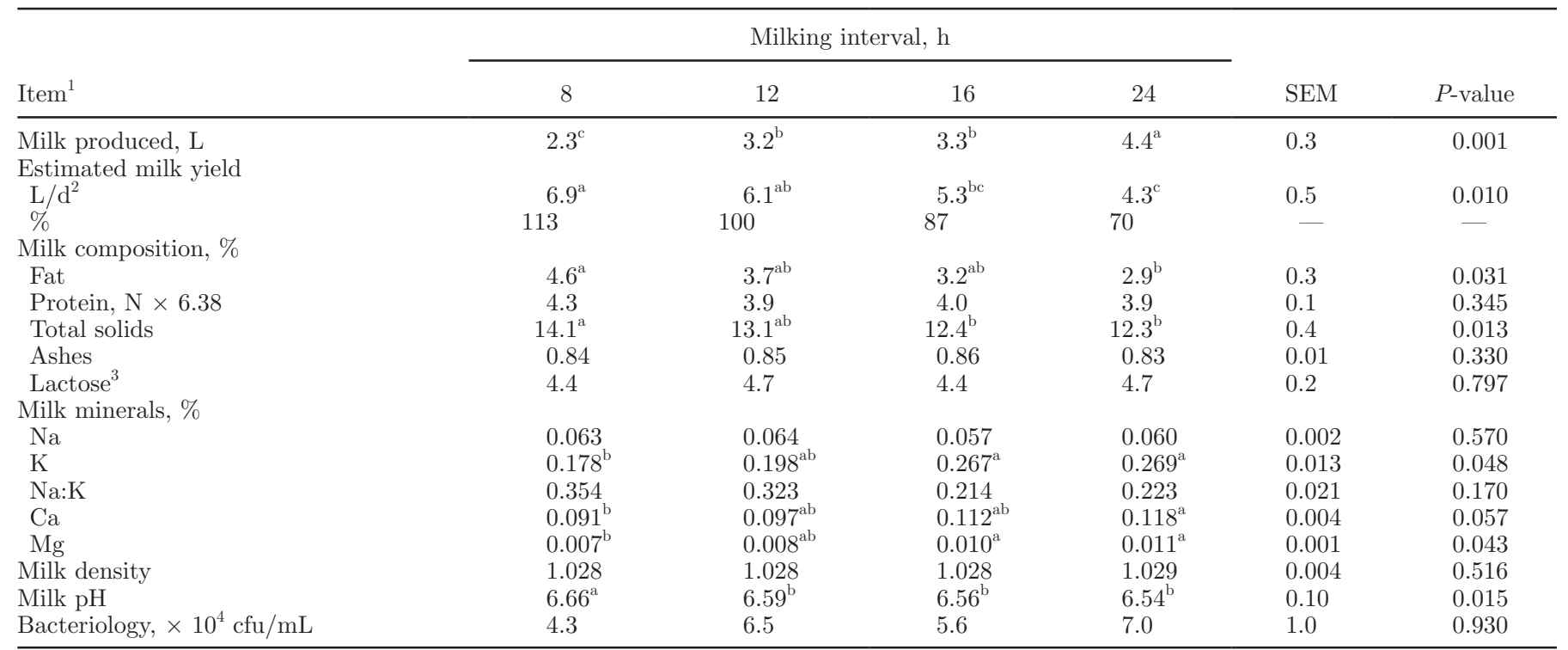

${ }^{\mathrm{a}-\mathrm{c}}$ Values with different superscript letters in the same row indicate significant differences at $P<0.05$.

${ }^{1}$ Values are least squares means.

${ }^{2}$ Estimated using the regression equation $\left(\mathrm{R}^{2}=0.997\right)$ : $\mathrm{y}(\mathrm{L} / \mathrm{d})=11.96-2.398 \mathrm{Ln}$ (milking interval, $\left.\mathrm{h}\right)$.

${ }^{3}$ Estimated by difference. 
Table 2. Milk component secretion rates for different milking intervals in Tunisian Maghrebi camels

\begin{tabular}{lcccccc}
\hline & \multicolumn{9}{c}{ Milking interval, $\mathrm{h}$} & & \\
\cline { 2 - 5 } Component, ${ }^{1} \mathrm{~g} / \mathrm{h}$ & 8 & 12 & 16 & 24 & SEM & $P$-value \\
\hline Fat & $13.6^{\mathrm{a}}$ & $9.0^{\mathrm{ab}}$ & $6.7^{\mathrm{b}}$ & $4.9^{\mathrm{b}}$ & 1.0 & 0.021 \\
Protein & $12.6^{\mathrm{a}}$ & $10.9^{\mathrm{ab}}$ & $8.5^{\mathrm{bc}}$ & $7.0^{\mathrm{c}}$ & 0.8 & 0.038 \\
Ash & $2.50^{\mathrm{a}}$ & $2.35^{\mathrm{a}}$ & $1.83^{\mathrm{ab}}$ & $1.55^{\mathrm{b}}$ & 0.24 & 0.049 \\
Total solids & $42.2^{\mathrm{a}}$ & $34.5^{\mathrm{ab}}$ & $25.8^{\mathrm{b}}$ & $22.5^{\mathrm{b}}$ & 2.5 & 0.020 \\
\hline
\end{tabular}

${ }^{a-c}$ Values with different superscript letters in the same row indicate significant differences at $P<0.05$.

${ }^{1}$ Values are least squares means.

Salah (1994). Predicted values of milk yield varied between 4.3 and $6.9 \mathrm{~L} / \mathrm{d}$ for 24- and 8-h milking intervals, respectively (Table 1 ), showing a maximum potential of approximately $8.1 \mathrm{~L} / \mathrm{d}$ and decreasing at a linear rate of approximately $162 \mathrm{~mL} / \mathrm{h}$.

The calculated reduction in camel milk yield $(-30 \%)$ for a milking interval equivalent to once-daily milking was similar to that indicated for dairy camels (Saley and Steinmetz, 1994), dairy cows (Stelwagen et al., 1994a; Rémond and Pomiès, 2005) and medium-cisterned dairy ewes (Castillo et al., 2008). Nevertheless, greater losses were reported for dairy cows $(-40 \%$ on average) in the review done by Erdman and Varner (1995).

Milk yield increase observed in our camels $(13 \%)$ when passing from milking intervals equivalent to twice- to thrice-daily milkings (12- to 8-h milking interval) was greater than the value reported by Alshaikh and Salah (1994) at similar milking intervals in late-lactation camels (4\%), but agrees with the average value of Erdman and Varner (1995) in dairy cows (18\%). A greater milk yield increase (29\%) was reported by Kamoun (1995) in Tunisian Maghrebi camels at midlactation. A detailed study of the data from Alshaikh and Salah (1994) reveals that milk yield value for 8-h milking interval may have been underestimated; the predicted value obtained by regression being $12 \%\left(\mathrm{R}^{2}=0.95\right)$, which agrees with our results.

\section{Milk Composition and Milk Components Secretion Rate}

Changes in milk composition according to milking interval are shown in Table 1. Total milk solids content decreased as milking interval increased, decreasing by $8 \%$ between the 8 - and 12 -h milking intervals and by $6 \%$ between 12 - and 16 -h milking intervals. After a 16-h milking interval, total milk solids content did not vary. Milk fat was the component most affected by milking interval, decreasing $37 \%$ between the extreme 8- and 24-h milking intervals. No differences were observed for the intermediate milking intervals. Fat and protein contents of the camel milk in our results were greater than values reported by Alshaikh and Salah (1994) and Haddadin et al. (2007), but in the range of those reported by Ohri and Joshi (1961) and Elamin and Wilcox (1992), which could be a consequence of individual, breed, and management differences, as well as of milking conditions (e.g., using oxytocin in our study).

Milk fat secretion rate also decreased markedly (64\%) between the extreme milking intervals (Table 2) as a consequence of the impairment of milk secretion when milking interval was extended. No differences in milk fat secretion rate were observed for the intermediate milking intervals. Our results agreed with those previously reported in dairy camels $(-46 \%$; Alshaikh and Salah, 1994) and in dairy cows (-27\%; Ayadi et al., 2004) for 4- to 16-h milking intervals, although a final increase in milk fat content was also observed by Ayadi et al. (2004) at extreme milking intervals (24 h) in dairy cows as a result of the steadied milk yield.

No differences in milk protein $(3.9 \pm 0.1 \%)$, lactose $(4.5 \pm 0.2 \%)$, and ash $(0.84 \pm 0.04 \%)$ contents were observed according to milking interval. Alshaikh and Salah (1994) reported slight decreases ( $-7 \%$ on average) in all milk components of camel milk when milking interval was increased. On the contrary, Ayadi et al. (2004) reported an increase in milk protein content according to milking interval (12\%) in dairy cows, which was attributed to an increase of TJ leakiness during milk stasis that allowed serum protein to spill over into the milk (Stelwagen et al., 1997; Ayadi et al., 2004). An increase in daily protein yield $(P<0.05)$ from 8 - $(101$ $\pm 14 \mathrm{~g} / \mathrm{d})$ to 24 -h $(170 \pm 12 \mathrm{~g} / \mathrm{d})$ milking intervals was observed in our results, which also agreed with the Ayadi et al. (2004) results in dairy cows.

Despite the reduction in milk components reported above, milk density did not vary by milking interval and averaged $1.029 \pm 0.002$, in agreement with the results of Farah (2004). On the other hand, milk pH decreased from the 8- to the 12-h interval and steadied thereafter. Average milk $\mathrm{pH}$ value $(6.59 \pm 0.05)$ was similar to values previously reported in dairy camels (Kamoun, 1995). 
Table 3. Cisternal and alveolar milk yield and composition at $24 \mathrm{~h}$ milking interval in dairy camels

\begin{tabular}{lcccc}
\hline & \multicolumn{2}{c}{ Udder compartment } & & \\
\cline { 2 - 3 } Item & Cisternal & Alveolar & SEM & $P$-value \\
\hline Milk yield, L & $0.329^{\mathrm{b}}$ & $1.380^{\mathrm{a}}$ & 0.151 & 0.001 \\
Milk composition, $\%$ & & & & 0.001 \\
Fat & $1.75^{\mathrm{b}}$ & $5.16^{\mathrm{a}}$ & 0.39 & 0.032 \\
Protein & $2.73^{\mathrm{b}}$ & $3.23^{\mathrm{a}}$ & 0.15 & 0.001 \\
Total solids & $9.52^{\mathrm{b}}$ & $13.42^{\mathrm{a}}$ & 0.46 & 0.018 \\
Ash & $0.95^{\mathrm{a}}$ & $0.91^{\mathrm{b}}$ & 0.01 & 0.867 \\
Lactose ${ }^{1}$ & 4.48 & 4.12 & 0.35 & 0.001 \\
Milk pH & $6.78^{\mathrm{a}}$ & $6.67^{\mathrm{b}}$ & 0.04 & 0.001 \\
Milk density & $1.027^{\mathrm{a}}$ & $1.023^{\mathrm{b}}$ & 0.001 & \\
${ }^{\mathrm{a}, \mathrm{b}}$ Values with different superscript letters in the same row indicate significant differences at $P<0.05$. \\
${ }^{1}$ Values are least squares means. & & & \\
${ }^{2}$ Estimated by difference. & & &
\end{tabular}

Changes in milk mineral composition according to milking interval are shown in Table 1. Milk K, Ca, and $\mathrm{Mg}$ contents increased with milking interval, whereas milk $\mathrm{Na}$ content did not change. Moreover, the milk Na:K ratio showed a tendency $(P<0.20)$ to decrease from 1:2.9 to $1: 4.5$ for the extreme milking intervals. Alshaikh and Salah (1994) also reported an increase in $\mathrm{K}$ secretion rate as milking interval increased, which has not been reported in other dairy species.

Secretion rate of total minerals (Table 2) was greatest at the 8-h interval and decreased as milking interval increased to $24 \mathrm{~h}$. No differences in secretion rates of milk $\mathrm{K}, \mathrm{Ca}$, and $\mathrm{Mg}$ were observed in our results when milking interval increased.

Total mineral content in camel milk found in our results was high compared with values reported by Elamin and Wilcox (1992) but similar to the values reported by Haddadin et al. (2007) in dairy camels. Although no values of total individual mineral contents were reported by Alshaikh and Salah (1994) for different milking intervals, our results disagree with the secretion rates of $\mathrm{Na}, \mathrm{K}, \mathrm{Ca}$, and $\mathrm{Mg}$ reported by these authors, for whom mineral secretion rates decreased with increasing milking interval. To our knowledge, there are no other data published for comparison.

Total bacteria counts in milk averaged $5.9 \pm 1.0 \times$ $10^{4} \mathrm{cfu} / \mathrm{mL}$ and no new intramammary infections were detected after the case described at the start of the experiment. Values reported for number of total aerobic mesophilic bacteria in camel milk range between $8 \times$ $10^{2}$ and $5 \times 10^{4} \mathrm{cfu} / \mathrm{mL}$ under extensive and intensive management conditions, respectively (Farah, 2004).

\section{Milk Partitioning in the Udder}

Data concerning the size of cisternal udder in dairy camels was used to understand the effect of milk stored in the udder on milk secretion rate at different milking intervals. With a 24-h milking interval, the ratio between cisternal and alveolar milk was approximately 1:4 (Table 3).

The percentage of cisternal milk obtained in our results at the 24-h milking interval was small when compared with values reported in dairy cows (38 to 46\%; Davis et al., 1998; Ayadi et al., 2003), dairy sheep (55 to $77 \%$; Castillo et al., 2008), and dairy goats (75\%; Salama et al., 2004), but greater than the cisternal milk values reported in dairy buffaloes at 12-h milking interval (5\%; Thomas et al., 2004). Our results disagree with those of Yagil et al. (1999), who assumed that camels do not have noticeable mammary cisterns, and of Baimukanov (1974) who suggested that camel cisternal milk represents only $10 \%$ of the total machinemilked milk.

Animals with large cisterns produce more milk, are milked faster and are more tolerant to longer milking intervals (Knight and Dewhurst, 1994; Ayadi et al., 2003). The relatively small cistern size observed in our results agreed with the impairment of milk secretion observed for extended milking intervals at late lactation. Consequently, efficient udder stimulation is recommended in Tunisian Maghrebi camels to maximize machine fraction and to minimize stripping fraction during machine milking.

As far as we know, there are no previous data studying the change in milk components of alveolar and cisternal milk compartments of the camel udder (Table 3). Fat content in alveolar milk was markedly greater $(295 \%$; $P<0.01)$ than in cisternal milk for the 24-h milking interval. This result agrees with those previously reported in dairy cows (Davis et al., 1998; Ayadi et al., 2004), dairy ewes (Castillo et al., 2008), and dairy goats (Salama et al., 2004), in which milk fat concentration is also markedly greater in alveolar than in cisternal milk. 


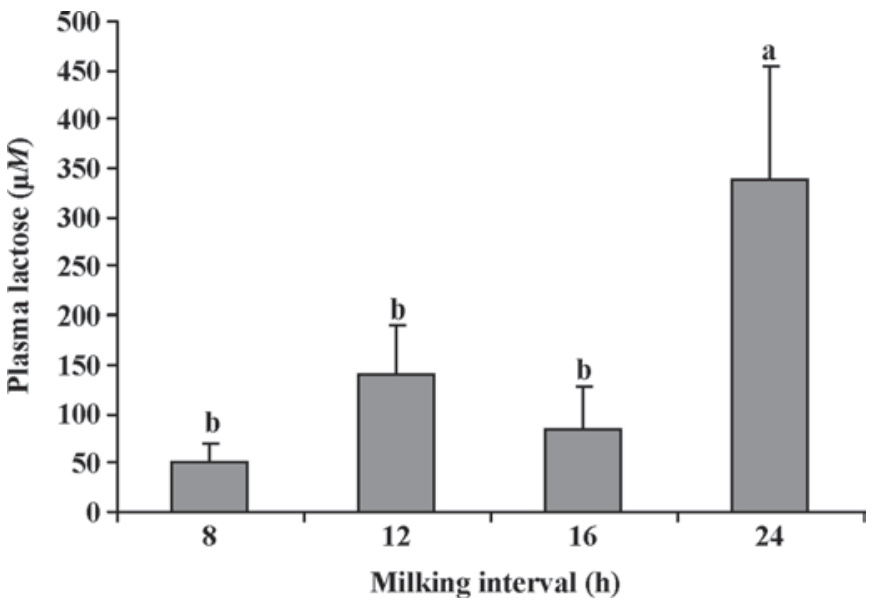

Figure 2. Lactose concentration in plasma according to milking interval in dairy camels (Different letters indicate significant differences at $P<0.05$; vertical bars represent SEM).

This difference can be explained by the viscosity and large size of fat globules which are accumulated in the alveolar compartment at extended milking intervals. Protein content in camel alveolar milk was also greater $(118 \% ; P<0.05)$ than in cisternal milk, which was unexpected and may be related to the special features of the camel casein with very low electrophoretic mobility and greater molecular weights than bovine caseins (Farah and Farah-Riesen, 1985). Camel results disagree with those obtained in dairy cows (Ayadi et al., 2004) and dairy sheep (Castillo et al., 2008) in which protein content in cisternal and alveolar milk are similar after $24 \mathrm{~h}$ of milk accumulation in the udder, although numerically greater values were observed on average in dairy sheep.

Milk total solids showed a similar trend to milk fat and protein contents (Table 3). Finally, alveolar milk was less dense and more acidic than cisternal milk (Table 3).

\section{Mammary TJ Opening}

The effect of milking interval on TJ opening in dairy camel was evidenced by changes in plasma lactose concentration shown in Figure 2. Stelwagen et al. (1994b) related the dramatic increase of lactose in plasma to TJ leakiness and to the reduction of milk secretion rate at long milking intervals in dairy goats. A similar decrease in milk yield (15\%) was observed by Stelwagen et al. (1995) by once-daily milking or by artificial opening of TJ using intramammary infusions of a Ca chelating agent in dairy goats.

Plasma lactose concentration did not vary in our results from 8 - to 16 -h milking intervals $(50 \pm 19$ and $84 \pm 45 \mu \mathrm{mol}$, respectively; $P>0.05)$ but showed a dramatic increase at 24-h milking interval $(338 \pm 118$ umol; $P<0.05$ ), indicating TJ opening after $16 \mathrm{~h}$ of milk accumulation. These results agree with those previously reported by Stelwagen et al. (1994a; 1997) and Delamaire and Guinard-Flament (2006) in dairy cows, in which lactose dramatically increased as a result of TJ leakiness 17 and $18 \mathrm{~h}$ after the last milking, respectively. Time for TJ opening in dairy sheep and dairy goats, which are more tolerant to extended milking intervals, is $20 \mathrm{~h}$ (Stelwagen et al., 1994b; Castillo et al., 2008). The reported TJ opening detected by means of the increase in blood lactose contrasted with the observed tendency to decrease $\mathrm{Na}: \mathrm{K}$ ratio in milk (Table 1) for the 24-h milking interval as a result of steadying $\mathrm{Na}$ and increasing $\mathrm{K}$ passage from blood to milk. Castillo et al. (2008) reported differences between dairy sheep breeds in Na:K ratio during milk accumulation in the udder, the Lacaune ewes (large-cisterned udders and tolerant to extended milking intervals) not showing an increase in the Na:K ratio in milk from 4- to 24-h milking interval when compared with Manchega (small-cisterned udders and not tolerant to extended milking intervals) .

According to Stelwagen et al. (1997) when the permeability of TJ increases, the concentration of $\mathrm{Na}$ in milk increases and the concentration of $\mathrm{K}$ decreases, resulting in a higher $\mathrm{Na}: \mathrm{K}$ ratio in the milk and intracellularly. This effect was not observed in the camel milk and is another specific finding of camel mammary glands that may be related to their adaptation to desert conditions. Alterations in the $\mathrm{Na}: \mathrm{K}$ ratio have been shown to interfere with several intracellular processes. Increased Na:K ratio reduced mammary protein synthesis in rabbit mammary gland explants (Falconer et al., 1978) and in dairy goats infused intramammarily with $\mathrm{Na}$ and K solutions (Stelwagen et al., 1999). This regulatory mechanism seems not to operate in camels in which TJ opening was associated with a decrease in $\mathrm{Na}$ K ratio and consequently did not show an impairment of milk protein synthesis when compared with milk yield.

\section{CONCLUSIONS}

In conclusion, extended milking intervals in dairy camels markedly reduced milk yield and decreased milk fat content and milk $\mathrm{pH}$, whereas minor changes were observed on milk protein, lactose, mineral contents, and milk density. This was in part a consequence of the small cisternal udders of the camel udder, the existence of which suggests the use of frequent milking including efficient prestimulation for machine milking and selection for increasing the volume of cisternal milk. Moreover, a late opening of mammary TJ was observed 
during extended milking intervals in camels, which may be related to a specific regulatory mechanism for controlling $\mathrm{Na}$ and $\mathrm{K}$ concentrations in milk. Further research is needed to explore in depth the consequences of this difference.

\section{ACKNOWLEDGMENTS}

This work was carried out in collaboration between the Institut Supérieur de Biologie Appliquée de Médenine (Université de Gabès) and the Institut des Régions Arides de Médenine. The authors thank Mabrouk Moldi Seddik and Ahmed Belgacem for the health care of the camels, Naceur Jarray and Arroum Samira (Institut des Régions Arides, Médenine, Tunisia) for the laboratory analysis, Xavier Such (Universitat Autònoma de Barcelona, Bellaterra, Spain) for providing the lactose analysis facilities, and Nic Aldam for the English revision of the manuscript.

\section{REFERENCES}

Alshaikh, M. A., and M. S. Salah. 1994. Effect of milking interval on secretion rate and composition of camel milk in late lactation. J. Dairy Res. 61:451-456.

Ayadi, M., G. Caja, X. Such, and C. H. Knight. 2003. Effect of omitting one milking weekly on lactational performances and morphological udder changes in dairy cows. J. Dairy Sci. 86:2352-2358.

Ayadi, M., G. Caja, X. Such, M. Rovai, and E. Albanell. 2004. Effect of different milking intervals on the composition of cisternal and alveolar milk in dairy cows. J. Dairy Res. 71:304-310.

Baimukanov, A. 1974. Machine milking of female camels. Pages 67-68 in Proc. 3rd Symp. Physiological Principles of Machine Milking, Borovsk, USSR.

Bruckmaier, R. M., D. Schams, and J. W. Blum. 1993. Milk removal in familiar and unfamiliar surroundings: Concentrations of oxytocin, prolactin, cortisol and $\beta$-endorphin. J. Dairy Res. 60:449-456.

Castillo, V., X. Such, G. Caja, R. Casals, E. Albanell, and A. A. K. Salama. 2008. Effect of milking interval on milk secretion and mammary tight junction permeability in dairy ewes. J. Dairy Sci. 91:2610-2619.

Davis, S. R., V. C. Farr, P. J. A. Copeman, V. R. Carruthers, C. H. Knight, and K. Stelwagen. 1998. Partitioning of milk accumulation between cisternal and alveolar compartments of the bovine udder: Relationship to production loss during once daily milking. J. Dairy Res. 65:1-8.

Delamaire, E., and J. Guinard-Flament. 2006. Longer milking intervals alter mammary epithelial permeability and the udder's ability to extract nutriments. J. Dairy Sci. 89:2007-2016.

El-Hatmi, H., T. Khorchani, M. Abdennebi, M. Hammadi, and H. Attia. 2004. Effects of diet supplementation on camel milk during the whole lactation under Tunisian arid range conditions. J. Camel Pract. Res. 11:147-151.

Elamin, F. M., and C. J. Wilcox. 1992. Milk composition of Majaheim camels. J. Dairy Sci. 75:3151-3157.

Erdman, R. A., and M. Varner. 1995. Fixed yield responses to increased milking frequency. J. Dairy Sci. 78:1199-1203.

Falconer, I. R., I. A. Forsyth, B. M. Wilson, and R. Dils. 1978. Inhibition by low concentrations of ouabain of prolactin-induced lactogenesis in rabbit mammary-gland explants. Biochem. J. 172:509-516.

Farah, Z. 2004. Camel milk. Pages 25-28 in Milk and Meat from Camel: Handbook on Products and Processing. Z. Farah and A. Fischer, ed. vdf Hochschulverlag, Zürich, Switzerland.
Farah, Z., and M. Farah-Riesen. 1985. Separation and characterization of the major components of camel milk casein. Milchwissenschaft 40:669-671.

Haddadin, M. S. Y., S. I. Gammoh, and R. K. Robinson. 2007. Seasonal variation in the chemical composition of camel milk in Jordan. J. Dairy Res. 10:1-5.

Hammadi, M., T. Khorchani, M. M. Seddik, H. El-Hatmi, M. Sghaier, A. Barmat, B. Fatnassi, and A. Ben Belgacem. 2006. Dairy potential of Maghrabi camel in intensive breeding system. Page 133 (Abstr.) in Proc. 1st Conf. Int. Soc. of Camelids Res. and Develop. (ISOCARD). Al-Ain, United Arab Emirates.

Hernández, L. L., C. M. Stiening, J. B. Wheelock, L. H. Baumgard, A. M. Parkhurst, and R. J. Collier. 2008. Evaluation of serotonin as a feedback inhibitor of lactation in the bovine. J. Dairy Sci. 91:1834-1844.

IDF. 1962. Determination of the protein content of milk. Standard No. 20. International Dairy Federation, Brussels, Belgium.

IDF. 1987. Milk, cream and evaporated milk - total solids. Standard No. 21B. International Dairy Federation, Brussels, Belgium.

IDF. 1991. Milk and milk products. Enumeration of micro organisms. Standard No. 100B. International Dairy Federation, Brussels, Belgium.

IDF. 1996. Milk and milk products. Preparation of samples and dilutions for microbiological examination. Standard No. 122C. International Dairy Federation, Brussels, Belgium.

Kamoun, M. 1995. Le lait de dromadaire: Production, aspects qualitatifs et aptitude à la transformation. Options Mediterr. B 13:105-130.

Knight, C. H., and R. J. Dewhurst. 1994. Once daily milking of dairy cows: Relationship between yield loss and cisternal milk storage. J. Dairy Res. 61:441-449.

Ohri, S. P., and B. K. Joshi. 1961. Composition of milk of camel. Indian Vet. J. 38:514-516.

Rémond, B., and D. Pomiès. 2005. Once-daily milking of dairy cows: A review of recent French experiments. Anim. Res. 54:427-442.

Salama, A. A. K., G. Caja, X. Such, S. Peris, A. Sorensen, and C. H. Knight. 2004. Changes in cisternal udder compartment induced by milking interval in dairy goats milked once or twice daily. J. Dairy Sci. 87:1181-1187.

Saley, M., and P. Steinmetz. 1994. Approche quantitative de la production laitière destinée à la consommation humaine, répercussion sur la croissance du chamelon. Pages 87-90 in Proc. Actes de l'Atelier: Chameaux et dromadaires, animaux laitiers, Nouakchott, Mauritanie.

Stelwagen, K., S. P. Davis, V. C. Farr, S. J. Eichler, and I. Politis 1994a. Effect of once daily milking and concurrent somatotropin on milk production and mammary tight junction permeability in cows. J. Dairy Sci. 77:2994-3002.

Stelwagen, K., S. R. Davis, V. C. Farr, C. G. Prosser, and R. A. Sherlock. 1994b. Mammary epithelial cell tight junction integrity and mammary blood flow during an extended milking interval in goats. J. Dairy Sci. 77:426-432.

Stelwagen, K., V. C. Farr, S. R. Davis, and C. G. Prosser. 1995. EGTA-induced disruption of epithelial cell tight junctions in the lactating caprine mammary gland. Am. J. Physiol. Regul. Integr. Comp. Physiol. 269:R848-R855.

Stelwagen, K., V. C. Farr, and H. A. McFadden. 1999. Alteration of the sodium to potassium ratio in milk and the effect on milk secretion in goats. J. Dairy Sci. 82:52-59.

Stelwagen, K., V. C. Farr, H. A. McFadden, C. G. Prosser, and S. R. Davis. 1997. Time course of milk accumulation-induced opening of mammary tight junctions, and blood clearance of milk components. Am. J. Physiol. Regul. Integr. Comp. Physiol. 273:R379-R386.

Thomas, C. S., K. Svennersten-Sjaunja, M. R. Bhosrekar, and R. M. Bruckmaier. 2004. Mammary cisternal size, cisternal milk and milk ejection in Murrah buffaloes. J. Dairy Res. 71:162-168.

Yagil, R., C. V. Creveld, G. Abu-R'kaib, and U. Merin. 1999. Milk let-down in camels. J. Camel Pract. Res. 6:27-29. 